\title{
Article \\ Comparative Analysis of Student Engagement in Digital Textbook Use during Quarantine
}

\author{
Kamal Moundy ${ }^{1, *(1)}$, Nadia Chafiq ${ }^{1}$ and Mohammed Talbi ${ }^{2}$ \\ 1 Observatory of Research in Didactics and University Pedagogy, Pluridisciplinary Laboratory of Sciences and \\ Techniques of Information, Communication and Education, Ben M'Sick Faculty of Sciences, Hassan II \\ University of Casablanca, Casablanca 20000, Morocco; nadia.chafiq@etu.univh2c.ma \\ 2 Observatory of Research in Didactics and University Pedagogy, Ben M'Sick Faculty of Sciences, Hassan II \\ University of Casablanca, Casablanca 20000, Morocco; mohammed.talbi@univh2m.ma \\ * Correspondence: kamalmoundy@gmail.com
}

Citation: Moundy, K.; Chafiq, N.; Talbi, M. Comparative Analysis of Student Engagement in Digital Textbook Use during Quarantine. Educ. Sci. 2021, 11, 352. https:// doi.org/10.3390/educsci11070352

Academic Editor: Eleanor Dommett

Received: 27 May 2021

Accepted: 9 July 2021

Published: 14 July 2021

Publisher's Note: MDPI stays neutral with regard to jurisdictional claims in published maps and institutional affiliations.

Copyright: (c) 2021 by the authors. Licensee MDPI, Basel, Switzerland. This article is an open access article distributed under the terms and conditions of the Creative Commons Attribution (CC BY) license (https:// creativecommons.org/licenses/by/ $4.0 /)$.

\begin{abstract}
Following the suspension of classes in Morocco due to the health crisis related to COVID19 , an adaptation of the pedagogical intervention of teaching is required. Distance learning is an essential lever contributing to ensuring the educational continuity of students. In this sense, our contribution is to ensure the educational continuity of students during the period of containment through the use of a digital manual. The digital textbook is made available to students of the 1st year of the qualifying secondary education. Through a tracking grid, we measured the student engagement during two different periods without and with the use of the digital textbook. The results show that the digital textbook was able to elicit student engagement in the completion of learning activities with a remarkable improvement of $57.1 \%$ in student engagement rate over the two periods $(t(273)=11.059, p<0.001)$. Student engagement while using a digital textbook can lead to better academic performance $(r=0.743, p=0.000<0.01)$. No one can deny the importance of distance learning as a powerful tool that allows teachers to improve their professional practices in the presence of solid, quality instruction in the classroom that promotes the acquisition of skills and the development of competencies in students.
\end{abstract}

Keywords: digital textbook; student engagement; school result; COVID-19; distance learning

\section{Introduction}

Nowadays, information and communication technologies (ICT) are at the heart of current events and are advancing with great speed to meet the requirements of the educational system. This means that it is unacceptable to hope to develop education without using ICT to improve the teaching-learning process. However, the role of ICT is not limited to the transmission and acquisition of knowledge, but rather to mobilize them effectively to bring added value to the pedagogical act by motivating students, diversifying educational resources, and improving the management of learning [1]. Today's students, born in the digital age or the "Google generation," prefer digital information sources and want to create their own personal-learning environment $[2,3]$.

Textbooks, generally published on paper, might seem outdated, while years have passed since the introduction of ICT [4]. The fact remains that the textbook, although physical and printed, is a simple and practical tool that can be used in various contexts, at specific times, to complement the teacher's work [5-7]. For this reason, the textbook remains a key tool that is difficult to overcome. Gerard and Rogiers [8] indicate that the integration of ICT brings opportunities for students to increase their relationship with knowledge and with peers. Previous research shows that student engagement with the digital textbook is related to academic achievement [9].

Today, schools are trying to present themselves and adapt to technological changes on the one hand, and on the other hand to preparing and attracting the digital generations. 
As a result, teachers have an increased responsibility for the teaching-learning process and school provision for this "digital age generation" can be an important contribution to improving the quality of education [10].

Studies have shown that the period of confinement has remarkable psychological consequences in adolescents [11]. Indeed, students who have undergone this difficult period have shown disengagement toward their studies because of the situation they live in. In the same sense, they reported that they spend their time using the different mobile devices they own and some of them have started to get addicted to video games. Regarding the Moroccan population, $88 \%$ of individuals in the 15-18 age group own a smartphone, and $26.8 \%$ of this group have a computer or tablet according to ANRT (National Telecommunications Regulatory Agency of Morocco, 2019) [12].

As ICT develops to meet the cognitive, institutional, and psychological demands of teaching, it is important to be aware of its impact on the educational process. The current health situation related to COVID-19 has already had a direct impact on the teaching methods adopted by the pedagogical stakeholders, which requires an adaptation on their part in order to succeed in their educational mission. Indeed, students and also teachers are finding it difficult to return to school, and to quickly put in place pedagogical practices and strategies to overcome the constraints of distance education [13].

The situation of the pandemic has challenged the educational systems of most countries, and more than $90 \%$ of learners are affected by this situation according to UNESCO. In this context, the main mission of institutions is to ensure pedagogical continuity by implementing an approach that transposes the habits of face-to-face teaching to distance, and to consider the motivation and commitment of students, and for teachers the design of courses and the supervision of students [14].

As part of the efforts made by the Ministry of National Education of Morocco to continue the pedagogical continuity of education in these exceptional conditions through distance education to supplement the curriculum and provide educational support to students by mobilizing digital educational resources to students and teachers and relying on the role of teachers to innovate. Furthermore, the main research question this study intends to answer is: to what extent can students develop their engagements through the use of a digital textbook?

In this respect, the contribution of ICT has proven to be necessary to overcome these challenges on the one hand and to ensure the commitment of most students on the other. In this sense, this research project constitutes a contribution allowing the teacher to better adapt to his reflection for more operationalization of his professional practices. Thus, our research goal is to contribute to ensuring the pedagogical continuity of students during the period of COVID-19 lockdown through the use of a digital textbook.

\section{The Theoretical Framework}

The textbook remains a fundamental element in the education system, especially in rural and peri-urban areas as well as areas with limited resources. According to Gérard and Rogiers [8], it is a tool that improves the efficiency of the learning process; according to Brugeilles and Cromer [15], an essential vector of learning; similarly, for Memaï and Rouag [16], a main vector of instruction and socialization, carrying knowledge, but also norms and values.

Concerning the digital textbook, no precise definition is agreed upon [17], the digital textbook is a complement or substitute for a physical paper textbook. It is not only handwritten texts, images, illustrations... but also multimodal resources: videos, audios (podcasts), educational software, exercises, games, hyperlinks, QR codes, images animated by augmented reality, learning platforms (spaces for teacher-student interaction) [17].

There are different digital textbooks classified into three types (Figure 1) [17,18]: 


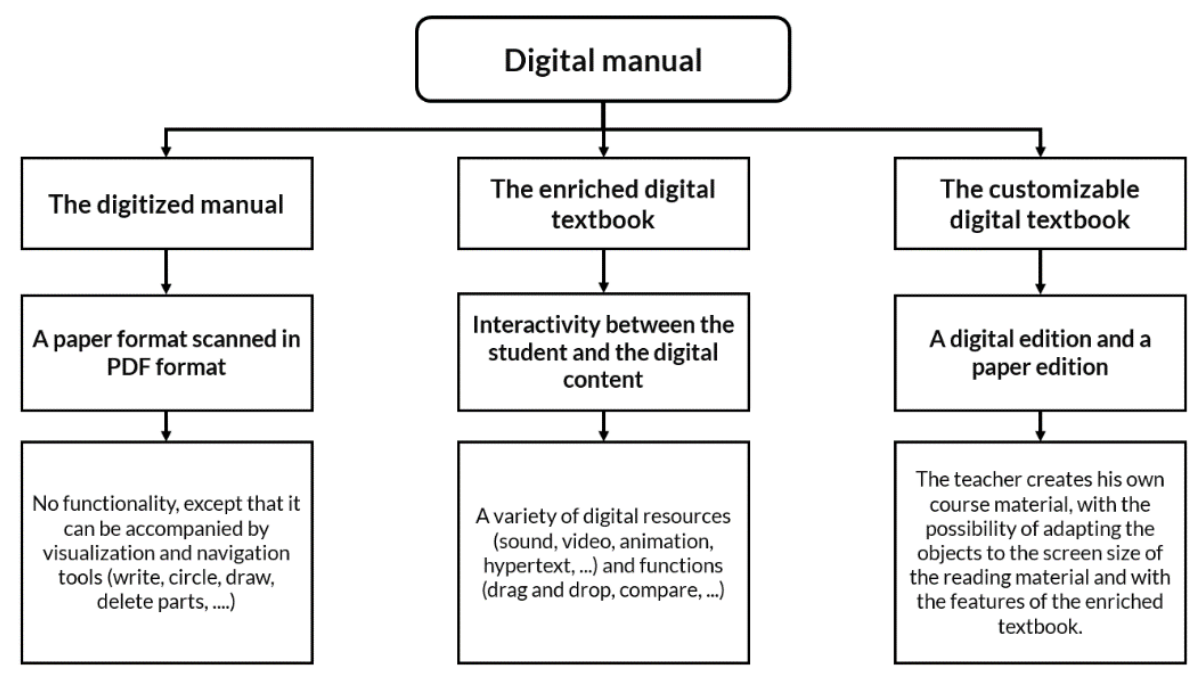

Figure 1. Types of digital textbooks.

Moving on to the design of the digital textbook, based on the steps in the development of the textbook by Gerard and Rogiers [8], we have opted for an organizational and methodical process (Figure 2) in order to achieve an adequate work, the process shows the main steps in the development of the digital textbook:

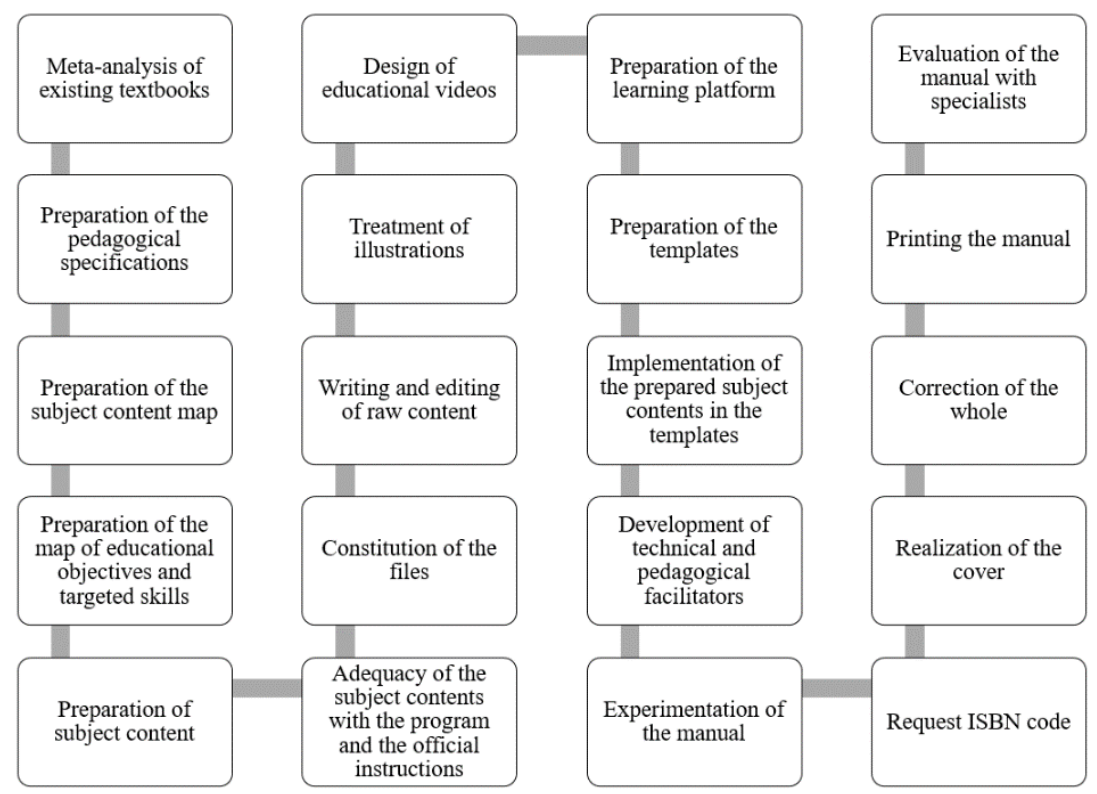

Figure 2. Stages in the development of the digital textbook.

We can say that the elaboration went through three phases, the first phase consists in analyzing and delimiting the project; the second phase consists in designing the content, the digital pedagogical resources, and the templates; and the last phase consists in evaluating, finalizing, and using the manual.

The digital textbook designed is of the customizable digital textbook type, which is the fate of a paper edition accompanied by digital resources, thus a fate of hybridization between the classic textbook and the digital textbook online. The textbook still has the missions of using it in class, but with new features to enrich and deepen with learning objects, pedagogical activities, or others, which are made available online to students and teachers.

At the second level, we opted for the methodological process of learning in the textbook, again based on Gerard and Roegiers [8], in order to establish a pedagogical 
alignment so that the learning objectives are consistent with the pedagogical activities and assessment strategies.

The construction of the learning sequences (Figure 3) involved a variety of methods, including starting problems, decontextualized situations, documents or objects to be observed, research, an anticipatory approach, a reminder of prerequisites, a demonstration or a simulation, illustrations, projects, summary diagrams, assessments of what has been learned, comprehension, consolidation, remediation, and improvement exercises.

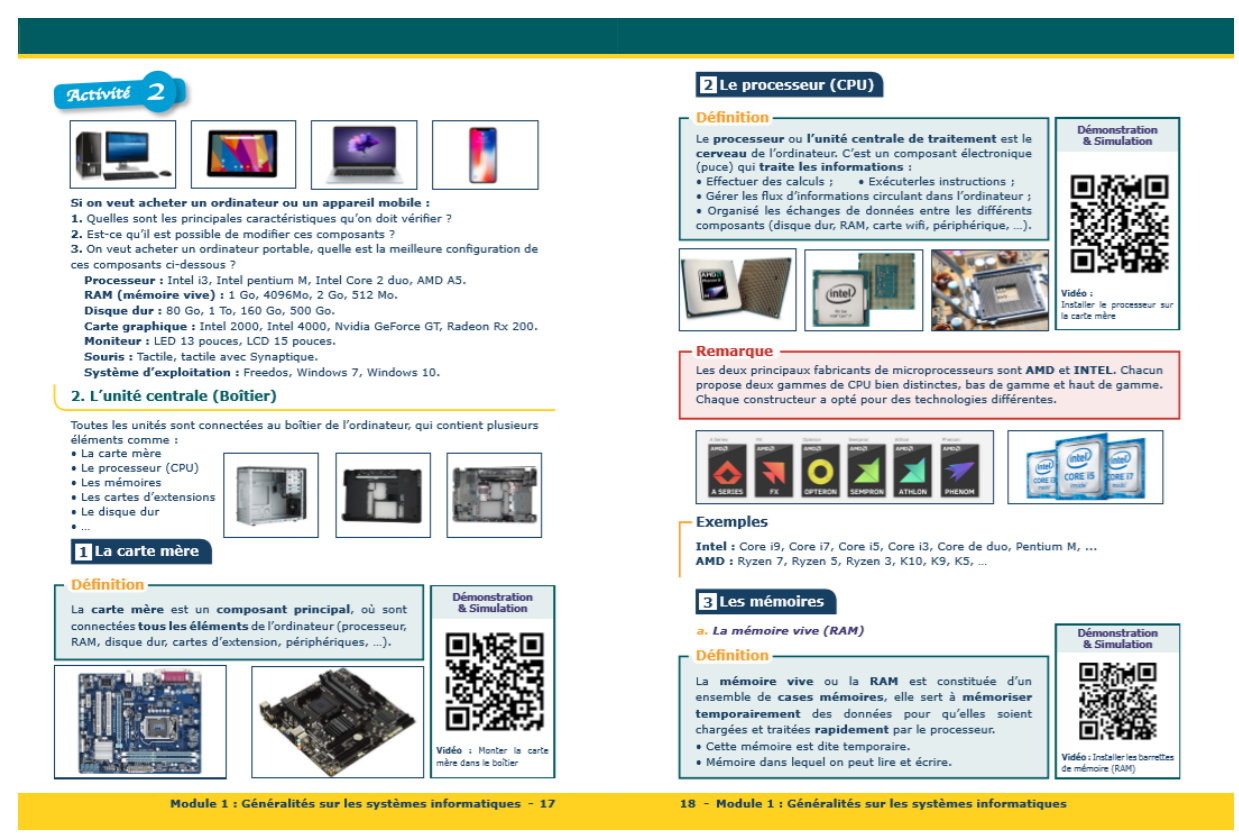

Figure 3. Screenshot of a learning sequence from the digital manual designed.

From a digital point of view, this digital textbook has diversified the digital educational resources, which are compatible and usable with a mobile device since most students do not have a computer. The manual includes complimentary digital documents, pedagogical videos of simulation or demonstration, educational software to perform or experiment a procedure, a learning platform where the teacher creates virtual classes for students to share information, communicate, and submit work, various exercises of difficulty, a space for sharing files, and $\mathrm{QR}$ codes and hyperlinks to facilitate access to digital resources.

\section{Materials and Methods}

\subsection{Characteristics of the Sample}

Our experiment was carried out in a secondary school in the provincial administration of Mediouna (an administrative district, independent but linked to the Academy of Casablanca-Settat) in the Kingdom of Morocco. In order to explore the problematic object of the research, we opted for a quantitative methodology carried out in an exploratory perspective. We conducted a survey of 352 first-year secondary-school students, including five classes in the scientific field (193 students) and four classes in the literary field (159 students).

The following two tables (Tables 1 and 2) show that the study population consists of students sharing more or less similar characteristics. For the scientific field, 193 students: $27.84 \%$ female and $26.99 \%$ male; also 159 students in the literary field: $22.73 \%$ female and $22.44 \%$ male. This population has an average age of 15.66 knowing that for the scientific field, the average age of women is 15.66, for men is 15.82 . About the literary field, the average age is 15.47 for women and 15.63 for men. 
Table 1. Number and proportion of students by gender, class, and field.

\begin{tabular}{|c|c|c|c|c|c|c|c|}
\hline & \multirow{3}{*}{ Class } & \multicolumn{6}{|c|}{ Gender } \\
\hline & & \multicolumn{2}{|c|}{ Female } & \multicolumn{2}{|c|}{ Male } & \multicolumn{2}{|c|}{ Total } \\
\hline & & Workforce & Proportion & Workforce & Proportion & Workforce & Proportion \\
\hline \multirow{6}{*}{$\begin{array}{l}\text { Scientific } \\
\text { field }\end{array}$} & Class 1 & 21 & $5.9 \%$ & 18 & $5.11 \%$ & 39 & $11.08 \%$ \\
\hline & Class 2 & 19 & $5.39 \%$ & 20 & $5.68 \%$ & 39 & $11.08 \%$ \\
\hline & Class 3 & 20 & $5.68 \%$ & 18 & $5.11 \%$ & 38 & $10.8 \%$ \\
\hline & Class 4 & 20 & $5.68 \%$ & 18 & $5.11 \%$ & 38 & $10.8 \%$ \\
\hline & Class $5 *$ & 18 & $5.11 \%$ & 21 & $5.9 \%$ & 39 & $11.08 \%$ \\
\hline & Total & 98 & $27.84 \%$ & 95 & $26.99 \%$ & 193 & $54.83 \%$ \\
\hline \multirow{5}{*}{ Literary field } & Class 1 & 19 & $5.39 \%$ & 20 & $5.68 \%$ & 39 & $11.08 \%$ \\
\hline & Class 2 & 21 & $5.9 \%$ & 21 & $5.9 \%$ & 42 & $11.93 \%$ \\
\hline & Class 3 & 19 & $5.39 \%$ & 20 & $5.68 \%$ & 39 & $11.08 \%$ \\
\hline & Class $4 *$ & 20 & $5.68 \%$ & 19 & $5.39 \%$ & 39 & $11.08 \%$ \\
\hline & Total & 79 & $22.44 \%$ & 80 & $22.73 \%$ & 159 & $45.17 \%$ \\
\hline \multicolumn{2}{|c|}{ Total } & 177 & $50.28 \%$ & 175 & $49.71 \%$ & 352 & $100 \%$ \\
\hline
\end{tabular}

Table 2. Average age of students by gender, class, and field.

\begin{tabular}{ccccc}
\hline & Class & \multicolumn{3}{c}{ Average Age } \\
\cline { 3 - 5 } & & Female & Male & Total \\
\hline \multirow{5}{*}{ Scientific field } & Class 1 & 15.44 & 15.82 & 15.63 \\
& Class 2 & 15.66 & 16.16 & 15.91 \\
& Class 3 & 15.86 & 15.76 & 15.81 \\
& Class 4 & 15.55 & 15.61 & 15.58 \\
& Class 5 & 15.79 & 15.75 & 15.77 \\
& Total & 15.66 & 15.82 & 15.74 \\
\hline \multirow{5}{*}{ Literary field } & Class 1 & 15.77 & 16.17 & 15.97 \\
& Class 2 & 15.33 & 15.23 & 15.28 \\
& Class 3 & 15.46 & 15.6 & 15.53 \\
& Class 4 & 15.33 & 15.55 & 15.44 \\
& Total & 15.47 & 15.63 & 15.55 \\
\hline
\end{tabular}

* This class will be considered as a control group.

\subsection{The Research Process}

Concerning the research methodology, it was carried out in two phases, the first one is designing a "digital" textbook of the computer science discipline based on the approach of François-Marie Gerard and Xavier Roegiers [8]. The second is a comparative study of two periods of distance learning with and without the use of the digital textbook for the duration of four weeks in order to appreciate the commitment to this health crisis related to COVID-19.

The research uses measurement instruments as research tools to collect data; we used a student-tracking grid to identify the rate of student engagement, as well as scheduled formative assessments to assess student progress toward the learning goal. With respect to the variables, the rate of student engagement is our dependent variable and academic achievement is the independent variable.

\subsection{Data Analysis Process}

Data analysis was performed using the SPSS ${ }^{\circledR}$ tool (version 25, Chicago, IL, USA). To answer the research question, the results were examined using descriptive statistical analysis. The results are analyzed by Student's Law (paired samples $t$-test and independent samples $t$-test) and Person's correlation coefficient. The results are presented as mean and standard deviation. The significance level is fixed $(p=0.01)$. 


\subsection{Implementation of the Manual}

The computer science digital textbook was already made available for students of the first year of qualifying secondary education at the beginning of the current school year in paper version. On 16 March 2020, the Ministry of National Education of Morocco announced the suspension of face-to-face classes in all educational and training institutions due to the COVID-19 pandemic, and to ensure pedagogical continuity through a distancelearning mode.

In order to achieve the research objective, we conducted a two-period comparative study of two groups:

- An experimental group consisting of five classes including four science classes and three literature classes. The first period, where the courses are implemented without the use of the digital textbook, contrary to the second period where the students benefit from the digital textbook as a teaching aid.

- A control group consisting of two classes of different specialties (scientific and literary). They start using the digital textbook in the first period.

Each period lasts two weeks: two sessions per week for one hour each.

The objective of the first week is to determine a charter of good conduct between the students and their teacher and to explain the project in its general sense, as well as the skills targeted and the expectations of the course.

During the first period of experimentation, the courses were broadcasted in a classical way. The teacher uses video conferencing applications (Zoom, Google Meet) to present his course and the various activities proposed for the student. In order to ensure the follow-up and the interactivity of the students, the teacher encourages his students to send their productions in form of photos, digital documents, etc.

The second period was based mainly on the use of the digital textbook with a mobile device and the learning platform where virtual classes were created as a space for exchange and sharing of information.

During these two periods, and with the aim of measuring the effectiveness of the digital textbook, we used a student-tracking grid to determine the rate of student engagement with the proposed educational activities.

The monitoring grid includes three criteria:

- A task engagement: counting the amount of time spent on a given task (student turned in work on the same day, after two days or " $n$ " days) and also the number of hours the student spends in the platform per day.

- Feedback: checking the student's interaction with the teacher or with peers, and its feedback in relation to the learning objects taught.

- Retroaction on mistakes: checking to see if the student has responded to the learning activities, and if they are beginning to make progress.

We fill in the grid with numerical responses between 0 and 3 (the Likert scale) of an even scale form to force the respondent to position themselves. This scale has the following values (3. very sufficient, 2 . somewhat sufficient, 1 . not very sufficient, 0 . not at all sufficient) for each student and during the four one-hour learning sessions of both periods.

At the end of each period, students take an assessment test (it is noted that the maximum score obtained in this test is $20 / 20$. We consider that having a mark higher than $10 / 20$ is quite good, higher than $15 / 20$ is very good) to verify the acquisition of the learning objects.

\section{Results}

\subsection{Student Engagement}

During the first period of distance learning, we obtained the following results (Table 3), which were extracted from the students' follow-up grid. We find that almost half of the students $(50.82 \%)$ were not engaged in this first period and the engagement rate is $41.33 \%$. 
Table 3. Student engagement rate and number of students engaged during the first period (experimental group).

\begin{tabular}{|c|c|c|c|c|c|c|}
\hline & & Session 1 & Session 2 & Session 3 & Session 4 & Average \\
\hline \multirow{3}{*}{$\begin{array}{l}\text { The Rate of } \\
\text { Student } \\
\text { Engagement }\end{array}$} & Total & $36.25 \%$ & $42.34 \%$ & $40.63 \%$ & $46.11 \%$ & $41.33 \%$ \\
\hline & Scientists & $44.62 \%$ & $52.12 \%$ & $51.32 \%$ & $56.87 \%$ & $51.23 \%$ \\
\hline & Literary & $27.88 \%$ & $32.56 \%$ & $29.94 \%$ & $35.35 \%$ & $31.43 \%$ \\
\hline \multirow{3}{*}{$\begin{array}{l}\text { The number of } \\
\text { engaged } \\
\text { students } \\
\text { (proportion) }\end{array}$} & Total & $\begin{array}{c}121 \\
(44.16 \%)\end{array}$ & $\begin{array}{c}139 \\
(50.73 \%)\end{array}$ & $\begin{array}{c}131 \\
(47.81 \%)\end{array}$ & $\begin{array}{c}148 \\
(54.01 \%)\end{array}$ & $(49.18 \%)$ \\
\hline & Scientists & $\begin{array}{c}77 \\
(50 \%)\end{array}$ & $\begin{array}{c}92 \\
(59.74 \%)\end{array}$ & $89(57.79 \%)$ & $\begin{array}{c}94 \\
(61.03 \%)\end{array}$ & $(57.14 \%)$ \\
\hline & Literary & $\begin{array}{c}44 \\
(36.67 \%)\end{array}$ & $\begin{array}{c}47 \\
(39.17 \%)\end{array}$ & $\begin{array}{c}42 \\
(35 \%)\end{array}$ & $\begin{array}{c}54 \\
(45 \%)\end{array}$ & $(38.96 \%)$ \\
\hline
\end{tabular}

We notice an increase in the number of engaged students (from 121 to 148 students), and similarly for the rate of student engagement, which has increased, we observe that the increase is unstable, sometimes it increases and sometimes it decreases. Assuming that the results of session 1 are neglected, we deduce that the rate of engagement varies between [ $40 \% ; 46 \%$ ]. Regarding the field of study, it can be seen that the rate of student engagement of scientific field students (51.23\%) is higher than that of literary field students $(31.43 \%)$.

It is noted that the engagement rate of both the scientific field and the literary field progressed during the four sessions between $[8 \% ; 10 \%]$, as did the number of students engaged.

In contrast to the control group, which progressed more rapidly with an engagement rate of $67 \%, 78.2 \%$ of the students were engaged (Table 4 ).

Table 4. Student engagement rate and number of students engaged during the first period (control group).

\begin{tabular}{|c|c|c|c|c|c|c|}
\hline & & Session 1 & Session 2 & Session 3 & Session 4 & Average \\
\hline \multirow{3}{*}{$\begin{array}{l}\text { The Rate of } \\
\text { Student } \\
\text { Engagement }\end{array}$} & Total & $58 \%$ & $69.69 \%$ & $70.99 \%$ & $69.26 \%$ & $67 \%$ \\
\hline & Scientists & $64.91 \%$ & $78.07 \%$ & $77.19 \%$ & $77.19 \%$ & $74.34 \%$ \\
\hline & Literary & $51.28 \%$ & $61.53 \%$ & $64.95 \%$ & $61.54 \%$ & $59.83 \%$ \\
\hline \multirow{3}{*}{$\begin{array}{l}\text { The number of } \\
\text { engaged } \\
\text { students } \\
\text { (proportion) }\end{array}$} & Total & $\begin{array}{c}57 \\
(73.07 \%)\end{array}$ & $\begin{array}{c}60 \\
(76.92 \%)\end{array}$ & $\begin{array}{c}60 \\
(76.92 \%)\end{array}$ & $\begin{array}{c}59 \\
(75.64 \%)\end{array}$ & $(78.2 \%)$ \\
\hline & Scientists & $\begin{array}{c}31 \\
(81.57 \%)\end{array}$ & $\begin{array}{c}33 \\
(84.62 \%)\end{array}$ & $\begin{array}{c}32 \\
(82.05 \%)\end{array}$ & $\begin{array}{c}32 \\
(82.05 \%)\end{array}$ & $(84.61 \%)$ \\
\hline & Literary & $\begin{array}{c}26 \\
(68.42 \%)\end{array}$ & $\begin{array}{c}27 \\
(69.23 \%)\end{array}$ & $\begin{array}{c}28 \\
(71.79 \%)\end{array}$ & $\begin{array}{c}27 \\
(69.23 \%)\end{array}$ & $(71.79 \%)$ \\
\hline
\end{tabular}

In the second period the students used the digital textbook under the guidance of their teacher. In general, we find that there is a significant change in the average student engagement rate compared to the two experimental periods (57.1\%) according to the following formula $=\frac{m_{\text {posttest }}-m_{\text {pretest }}}{m_{\text {prettest }}} \times 100$ (Tables 3 and 5).

We notice that the rate of the engaged students after session 1 is more or less constant in the same way as the first period between 62 and $65 \%$. Of course, the average number of engaged students is $73.17 \%$, and more than $25 \%$ of the students are not engaged or do not attend the classes regularly.

Noting that both fields exceeded the half mark (50\%), the engagement rate of the scientific fields remained consistently higher than the literary ones $(70.47 \%$ compared to $59.3 \%)$.

However, we note a considerable decrease in the engagement rate of students in the control group during the second period by almost $50 \%$ (Table 6). 
Table 5. Student engagement rate and number of students engaged during the second period (experimental group).

\begin{tabular}{|c|c|c|c|c|c|c|}
\hline & & Session 1 & Session 2 & Session 3 & Session 4 & Average \\
\hline \multirow{3}{*}{$\begin{array}{l}\text { The Rate of } \\
\text { Student } \\
\text { Engagement }\end{array}$} & Total & $64.11 \%$ & $62.27 \%$ & $65.33 \%$ & $63.01 \%$ & $64.93 \%$ \\
\hline & Scientists & $70.63 \%$ & $72.13 \%$ & $70.68 \%$ & $68.43 \%$ & $70.47 \%$ \\
\hline & Literary & $57.59 \%$ & $62.41 \%$ & $59.98 \%$ & $57.59 \%$ & $59.39 \%$ \\
\hline \multirow{3}{*}{$\begin{array}{l}\text { The number of } \\
\text { engaged } \\
\text { students } \\
\text { (proportion) }\end{array}$} & Total & $\begin{array}{c}197 \\
(71.9 \%)\end{array}$ & $\begin{array}{c}205 \\
(74.81 \%)\end{array}$ & $\begin{array}{c}202 \\
(73.72 \%)\end{array}$ & $\begin{array}{c}198 \\
(72.26 \%)\end{array}$ & $(73.17 \%)$ \\
\hline & Scientists & $\begin{array}{c}120 \\
(77.92 \%)\end{array}$ & $\begin{array}{c}123 \\
(79.87 \%)\end{array}$ & $\begin{array}{c}121 \\
(78.57 \%)\end{array}$ & $\begin{array}{c}120 \\
(77.92 \%)\end{array}$ & $(78.57 \%)$ \\
\hline & Literary & $\begin{array}{c}77 \\
(64.17 \%)\end{array}$ & $\begin{array}{c}82 \\
(68.33 \%)\end{array}$ & $\begin{array}{c}81 \\
(67.5 \%)\end{array}$ & $\begin{array}{c}78 \\
(65 \%)\end{array}$ & $(66.25 \%)$ \\
\hline
\end{tabular}

Table 6. Student engagement rate and number of students engaged during the second period (control group).

\begin{tabular}{|c|c|c|c|c|c|c|}
\hline & & Session 1 & Session 2 & Session 3 & Session 4 & Average \\
\hline \multirow{3}{*}{$\begin{array}{l}\text { The Rate of } \\
\text { Student } \\
\text { Engagement }\end{array}$} & Total & $58.87 \%$ & $51.51 \%$ & $42.85 \%$ & $45.02 \%$ & $49.56 \%$ \\
\hline & Scientists & $68.42 \%$ & $59.64 \%$ & $49.12 \%$ & $51.75 \%$ & $57.23 \%$ \\
\hline & Literary & $49.57 \%$ & $43.58 \%$ & $36.75 \%$ & $38.46 \%$ & $42.09 \%$ \\
\hline \multirow{3}{*}{$\begin{array}{l}\text { The number of } \\
\text { engaged } \\
\text { students } \\
\text { (proportion) }\end{array}$} & Total & $\begin{array}{c}49 \\
(62.82 \%)\end{array}$ & $\begin{array}{c}45 \\
(57.69 \%)\end{array}$ & $\begin{array}{c}43 \\
(55.12 \%)\end{array}$ & $\begin{array}{c}45 \\
(57.69 \%)\end{array}$ & $(58.33 \%)$ \\
\hline & Scientists & $\begin{array}{c}28 \\
(71.79 \%)\end{array}$ & $\begin{array}{c}25 \\
(64.1 \%)\end{array}$ & $\begin{array}{c}24 \\
(61.53 \%)\end{array}$ & $\begin{array}{c}25 \\
(64.1 \%)\end{array}$ & $(65.38 \%)$ \\
\hline & Literary & $\begin{array}{c}21 \\
(55.26 \%)\end{array}$ & $\begin{array}{c}20 \\
(52.63 \%)\end{array}$ & $\begin{array}{c}19 \\
(50 \%)\end{array}$ & $\begin{array}{c}20 \\
(52.63 \%)\end{array}$ & $(52.63 \%)$ \\
\hline
\end{tabular}

The following table (Table 7) shows the results of the normality tests of the two periods (period 1 and period 2), we have a significance value of 0.000 for both periods which is well above the significance level of $p$-value 0.05 which allows us to conclude that the normality of the data is normal for both periods.

Table 7. Normality tests-Kolmogorov-Smirnov.

\begin{tabular}{cccc}
\hline & Statistics & ddl & $p$-Value \\
\hline Period 1 & 0.287 & 273 & 0.000 \\
Period 2 & 0.301 & 273 & 0.000 \\
\hline
\end{tabular}

In these results (Table 8), the average of the differences in the rate of student engagement of the two periods is $m=0.23628(\mu=0.35364)$. As well as the results obtained are highly significant $t(273)=11.059, p<0.01$.

Table 8. Student's test of paired samples-paired differences.

\begin{tabular}{|c|c|c|c|c|c|c|c|c|}
\hline & \multirow{2}{*}{ Average } & \multirow{2}{*}{$\begin{array}{l}\text { Standard } \\
\text { Deviation }\end{array}$} & \multirow{2}{*}{$\begin{array}{l}\text { Average Standard } \\
\text { Error }\end{array}$} & \multicolumn{2}{|c|}{$\begin{array}{l}\text { Confidence Interval of the } \\
\text { Difference at } 95 \%\end{array}$} & \multirow[t]{2}{*}{$t$} & \multirow{2}{*}{ ddl } & \multirow[t]{2}{*}{$p$-Value } \\
\hline & & & & Lower & Superior & & & \\
\hline Period 1-Period 2 & -0.23628 & 0.35364 & 0.02136 & -0.27834 & -0.19422 & -11.059 & 273 & 0.000 \\
\hline
\end{tabular}

The results in the table (Table 5) show that the science students are more engaged with a rate of $(78.75 \%)$, while the literature students have a rate of $(66.25 \%)$. The difference between the two groups is therefore significant for both periods; period 1 ( $t$-test $=4.088$, $\mathrm{ddl}=272, p=0.000)$ and period $2(t$-test $=2.290, \mathrm{ddl}=272, p=0.023)($ Table 9). 
Table 9. Student's $t$ test for independent samples-periods 1 and 2.

\begin{tabular}{|c|c|c|c|c|c|c|c|c|c|c|}
\hline & & \multicolumn{2}{|c|}{$\begin{array}{c}\text { Levene's Test for } \\
\text { Equality of } \\
\text { Variances }\end{array}$} & \multicolumn{7}{|c|}{$t$-Test for Equality of Means } \\
\hline & & \multirow[t]{2}{*}{ F } & \multirow[t]{2}{*}{$p$-Value } & \multirow[t]{2}{*}{$t$} & \multirow[t]{2}{*}{ ddl } & \multirow{2}{*}{$\begin{array}{l}p \text {-Value } \\
\text { (Two- } \\
\text { Sided) }\end{array}$} & \multirow[t]{2}{*}{$\begin{array}{l}\text { Average } \\
\text { Difference }\end{array}$} & \multirow{2}{*}{$\begin{array}{l}\text { Standard } \\
\text { Error } \\
\text { Difference }\end{array}$} & \multicolumn{2}{|c|}{$\begin{array}{c}\text { Confidence } \\
\text { Interval of the } \\
\text { Difference at } 95 \% .\end{array}$} \\
\hline & & & & & & & & & Lower & Superior \\
\hline \multirow{2}{*}{ Period 1} & $\begin{array}{l}\text { Hypothesis of } \\
\text { equal variances }\end{array}$ & 13.178 & 0.000 & 4.088 & 272 & 0.000 & 0.21168 & 0.05178 & 0.10973 & 0.31363 \\
\hline & $\begin{array}{l}\text { Unequal variances } \\
\text { assumption }\end{array}$ & & & 4.147 & 267.121 & 0.000 & 0.21168 & 0.05105 & 0.11117 & 0.31218 \\
\hline \multirow{2}{*}{ Period 2} & $\begin{array}{l}\text { Hypothesis of } \\
\text { equal variances }\end{array}$ & 10.482 & 0.001 & 2.290 & 272 & 0.023 & 0.11639 & 0.05081 & 0.01635 & 0.21643 \\
\hline & $\begin{array}{l}\text { Unequal variances } \\
\text { assumption }\end{array}$ & & & 2.259 & 240.640 & 0.025 & 0.11639 & 0.05153 & 0.01488 & 0.21790 \\
\hline
\end{tabular}

\subsection{The Correlation of Student Engagement Rates and Academic Outcomes}

After the four sessions of each period, the students took a formative evaluation, which allowed us to assess the student's progress toward the pedagogical objectives.

Concerning period $1,54.01 \%$ of the students passed the evaluation with an average mark of 14.56 . However, we note that the number of students evaluated reached 206 students $(75.18 \%$ ) in period 2 (Table 10$)$.

Table 10. The number of students assessed, and their grade point averages during the two experimental periods.

\begin{tabular}{ccccccc}
\hline & & Period 1 & & \multicolumn{3}{c}{ Period 2 } \\
\cline { 2 - 7 } & Scientists & Literary & Total & Scientists & Literary & Total \\
\hline $\begin{array}{c}\text { Students who took the } \\
\text { assessment }\end{array}$ & 94 & 54 & 148 & 123 & 83 & 206 \\
Average score & $(61.04 \%)$ & $(45 \%)$ & $(54.01 \%)$ & $(79.87 \%)$ & $(69.17 \%)$ & $(75.18 \%)$ \\
\hline
\end{tabular}

The table presents the correlation between the students' rate of engagement and academic performance during the experimental period. Indeed, it shows a positive and highly significant relationship $(r=0.743, p=0.000<0.01)$ (Table 11).

Table 11. The correlation of students' engagement rate and their academic grades during period 2.

\begin{tabular}{|c|c|c|c|}
\hline & & Engagement Rate & School Grade \\
\hline \multirow{3}{*}{ Engagement rate } & Pearson correlation & 1 & $0.743^{* *}$ \\
\hline & Sig. (bilateral) & & 0.000 \\
\hline & $\mathrm{N}$ & 274 & 206 \\
\hline \multirow{3}{*}{ School grade } & Pearson correlation & $0.743^{* *}$ & 1 \\
\hline & Sig. (bilateral) & 0.000 & \\
\hline & $\mathrm{N}$ & 206 & 206 \\
\hline
\end{tabular}

** Correlation is significant at the 0.01 level (two-tailed).

When controlled by field (scientific and literary) we note that the control effect on partial inter-trait correlations is significant and large (Table 12).

These results are confirmed by our analysis of the assessment results. It appears that students with grades greater than or equal to $10 / 20$ have an engagement rate of up to $87.5 \%$. In the same direction, an engagement rate reaches $94.24 \%$ for students with a grade greater than or equal to $15 / 20$ (Table 13). 
Table 12. The correlation of students' rate of engagement and their academic grades controlled by field in period 2.

\begin{tabular}{|c|c|c|c|c|}
\hline & & & Engagement Rate & School Grade \\
\hline \multirow{6}{*}{ Field (control variable) } & \multirow{3}{*}{ Engagement rate } & Pearson correlation & 1 & 0.743 \\
\hline & & Sig. (bilateral) & & 0.000 \\
\hline & & ddl & 0 & 203 \\
\hline & \multirow{3}{*}{ School grade } & Pearson correlation & 0.743 & 1 \\
\hline & & Sig. (bilateral) & 0.000 & \\
\hline & & ddl & 203 & 0 \\
\hline
\end{tabular}

Table 13. Student engagement rates by academic achievement.

\begin{tabular}{|c|c|c|c|c|}
\hline & & Scientist & Literary & Total \\
\hline \multirow{2}{*}{ Students with a grade of $10 / 20$ or higher } & Workforce & $\begin{array}{c}121 \\
(78.57 \%)\end{array}$ & $\begin{array}{c}81 \\
(67.5 \%) \\
\end{array}$ & $\begin{array}{c}202 \\
(73.72 \%) \\
\end{array}$ \\
\hline & Engagement rate & $88.56 \%$ & $85.9 \%$ & $87.5 \%$ \\
\hline \multirow{2}{*}{ Students with a grade of $15 / 20$ or higher } & Workforce & $\begin{array}{c}67 \\
(43.51 \%)\end{array}$ & $\begin{array}{c}32 \\
(26.27 \%)\end{array}$ & $\begin{array}{c}99 \\
(36.13 \%)\end{array}$ \\
\hline & Engagement rate & $98.88 \%$ & $100 \%$ & $99.24 \%$ \\
\hline
\end{tabular}

\section{Discussion}

First, let us recall that the goal of our research is to help ensure pedagogical continuity for students during the lockdown period by using a digital textbook. To do so, we formulated the following question: To what extent can students develop their engagements through the use of a digital textbook?

We will discuss the findings in light of our purpose, and in light of previous research.

First of all, we opted for two experimental periods, the first one based on distance learning without the use of the digital textbook and the second one, on the same conditions using the digital textbook. During these two periods, we accompanied the students during the experimentation using a follow-up grid in order to assess their commitment, and we obtained the following results.

The digital textbook was able to engage students in the completion of learning activities, which is supported by the results obtained showing that the rate of student engagement in the second period was very average (64.93\%).

Note that a significant change was noticed in the average rate of student engagement compared to the two experimental periods (57.1\%), as well for the control groups who showed an important engagement rate $(67 \%)$ using the digital textbook.

These results were confirmed by the work of Junco and Clem [9] who consider the digital textbook and student engagement to be related. Similarly, Dennis [19] reported that 36 to $84 \%$ of the students preferred to use a digital textbook and it can go up to $87 \%$ if they can choose [20].

From a design and presentation point of view, they express the importance of this aspect for some students who may find it attractive [4] and therefore, it will influence their commitment to learn or even better their psychological profiles [9].

Our second results showed that students' engagement during the use of a digital textbook can lead to better academic results; they present a positive and highly significant relationship $(\mathrm{r}=0.743, p=0.000<0.01)$. When this relationship is controlled by field, we notice that the control effect on the partial inter-trait correlations is significant and large $(p=0.000<0.01)$. As for the grade obtained, it varies according to the rate of engagement, for example; students with a grade of 10 or more have a rate of engagement of $87.5 \%$.

These findings have been confirmed by some of the work of Pascarella and Terenzini [21] who consider student engagement to be directly related to academic achievement. 
Chickering and Gamson [22] assert that increased time spent on a learning activity and active learning should lead to better academic outcomes. In the same vein, Daniel and Woody [23] and Landrum [24] state that student engagement related to textbook use has a significant relationship with academic outcomes, and Junco and Clem [9] express that students who engage with digital textbooks will be expected to achieve higher grades.

Relating to the field, scientific students show more engagement $(70.47 \%)$ during the use of the digital textbook than literary students (59.39\%). According to Pittet and Eberhard [25], so-called scientific students have a concrete, logical, and precise approach to objects. Computer science is a teaching discipline with a logical, concrete, and precise approach.

Nevertheless, we found that more than $25 \%$ of the students were not present to follow the distance learning, or if they were present, they did not show any signs of presence. We linked this cause to several reasons: demotivation or disinterest of the student, stress related to the sanitary measures of COVID-19 (confinement), lack or inadequacy of mobile and nomadic equipment in households, lack of a device for access to the Internet, the grades of the assessments made in this period will not be considered on the report cards of students, family leaders have been suspended from their jobs which causes a demotivation of students to learn.

Similarly, the High Commission for Planning of Morocco [26] conducted a survey during this confinement, they found that $69 \%$ of students in qualifying secondary education regularly followed distance courses ( $21 \%$ irregular and $10 \%$ no follow-up), this is a rate close to that which we found that $73.17 \%$ of students engaged in this mode of distance learning.

However, some research studies insist on the autonomy of the student in the distance mode. Indeed, learners at certain ages need rigorous guidance and monitoring, which is not possible during the distance course [27]. Davies et al. [28] also talk about the security aspect related to the loss of the device and disrespectful use, putting the focus on the nature of the device used (mobile device, computer).

In relation to the Moroccan context, and according to a report by ANRT [12] on the availability of a mobile device among Moroccan students, a significant number of young people in school do not have a mobile device, especially in the rural world which constitutes our field of study. This will put into question the equality of opportunities and promotes social differences.

The results showed some limitations worth mentioning:

- The use of a non-validated tracking grid is a major limitation of our research and subsequently impacts the validity and reliability of the results.

- The experimentation focused on a single context (Mediouna Provincial Directorate).

- The experimental part focused on two teaching fields: Scientific and literary because of the availability and accessibility of the sample.

- Vary the levels and cycles of education to give more completeness.

- We believe that the time devoted to each period of the experimentation was insufficient due to the end of the school season.

- We did not take into consideration the teachers' commitment and motivation toward this teaching approach, let alone their attitude during the experiment.

\section{Conclusions}

The digital textbook is based on a balance that is increasingly satisfactory and less stable, between the editorial offer and the expectations of the institution, between the digital tools devoted to it and the pedagogical benefits, between the demand of teachers and the needs of students, between the classic model of the printed textbook and the potential of digital technology.

The goal of our research is to help ensure educational continuity for students during the lockdown period by using a digital textbook.

The digital textbook remains a powerful tool, facilitating the teacher's intervention and providing a frame of reference for students to build their learning on a strong foundation. 
The use of the digital textbook was able to significantly increase student engagement in learning activities, and that this engagement can lead to better academic results.

No one can deny the importance of distance education as an innovative approach that allows teachers to perfect their professional practices in the presence of a solid, quality teaching in the classroom that promotes the acquisition of skills and the development of competencies in students.

To follow-up on the results, we propose:

- Generalize the experience of the digital textbook to other school subjects.

- Setting up a continuous training system for teachers.

- Provide the necessary material and software resources for rural and peri-urban areas and areas with limited resources (tablets, computers, Internet networks, etc.).).

- Institutionalize distance-learning practices by the Ministry of National Education.

- Institutions must be part of this approach by encouraging students on the advantages of distance learning.

- The proposed educational activities must be unified in consultation with each educational team in the institution.

- Parents play an essential role in tracking their students and encouraging them to take their courses at a distance.

- Conducting conferences, virtual meetings, or workshops that raise awareness of the importance of digitization.

- The digital educational resources designed must work on different operating systems and different graphic interfaces.

- The pedagogical direction must be a part of the accompaniment and tracking of teachers and students in their practices.

- A comparison between the students' academic performance before and after the use of the digital textbook will be made to determine its effect on their academic grades

Author Contributions: Conceptualization, N.C. and K.M.; methodology, N.C. and M.T.; software, K.M.; validation, N.C., M.T. and K.M.; formal analysis, N.C.; investigation, K.M.; resources, K.M.; data curation, K.M.; writing — original draft preparation, K.M.; writing—review and editing, K.M.; visualization, N.C.; supervision, N.C. and M.T.; project administration, N.C. and M.T.; funding acquisition, K.M. All authors have read and agreed to the published version of the manuscript.

Funding: This research received no external funding.

Institutional Review Board Statement: Ethical review and approval were waived for this study. In fact, one of the authors is a teacher. Therefore, there is no problem because he has the right to do this kind of research on his own student.

Informed Consent Statement: Informed consent was obtained from all subjects involved in the study.

Data Availability Statement: The data presented in this study are available on request from the corresponding author. The data are not publicly available due to confidential reasons.

Conflicts of Interest: The authors declare no conflict of interest.

\section{References}

1. Collin, S.; Karsenti, T. Les TIC en éducation: Ni panacée, ni supercherie. Québec Français 2012, 166, 70-71.

2. Tonkery, D. E-books come of age with their readers. Res. Inf. 2006, 24, 26-27.

3. Rowlands, I.; Nicholas, D.; Williams, P.; Huntington, P.; Fieldhouse, M.; Gunter, B.; Withey, R.; Jamali, H.R.; Dobrowolski, T.; Tenopir, C. The Google generation: The information behaviour of the researcher of the future. Aslib Proc. 2008, 60, $290-310$. [CrossRef]

4. Dutrieux, L. De Quelles Manières la Mise en Page et la Présentation Graphique des Manuels Scolaires Peuvent-Elles Aider le Jeune en Apprentissage? Available online: https://medium.com/liove/de-quelles-mani\%C3\%A8res-la-mise-en-page-et-la-pr\% C3\%A9sentation-graphique-des-manuels-scolaires-peuvent-1afdca651ea2 (accessed on 24 May 2021).

5. Elias, E.C.; Phillips, D.C.; Luechtefeld, M.E. E-books in the classroom: A survey of students and faculty at a school of pharmacy. Curr. Pharm. Teach. Learn. 2012, 4, 262-266.e1. [CrossRef]

6. Rose-Wiles, L.M.; Irwin, J.P. An old horse revived? J. Acad. Libr. 2016, 42, 207-214. [CrossRef] 
7. Wang, S.; Bai, X. University students awareness, usage and attitude towards e-books: Experience from China. J. Acad. Libr. 2016, 42, 247-258. [CrossRef]

8. Gérard, F.-M.; Roegiers, X. Des Manuels Scolaires Pour Apprendre; De Boeck Supérieur; Groupe De Boeck: Brussels, Belgium, 2009.

9. Junco, R.; Clem, C. Predicting course outcomes with digital textbook usage data. Internet High. Educ. 2015, 27, 54-63. [CrossRef]

10. Flores, P.Q.; Ramos, A.; Escola, J. The Digital Textbook: Methodological and Didactic Challenges for Primary School; Rodríguez, J., Bruillard, E., Horsley, M., Eds.; USC/IARTEM: Santiago de Compostela, Spain, 2015; pp. 275-295.

11. Villani, L.; Pastorino, R.; Molinari, E.; Anelli, F.; Ricciardi, W.; Graffigna, G.; Boccia, S. Impact of the COVID-19 pandemic on psychological well-being of students in an Italian university: A web-based cross-sectional survey. Global. Health 2021, 17, 39. [CrossRef] [PubMed]

12. ANRT. Enquête de Collecte Des Indicateurs TIC Auprès Des Ménages et Des Individus Au Niveau National Au Titre de l'année 2018; ANRT: Rabat, Morocco, 2019.

13. Borges, C.; Tardif, M.; Karsenti, T. Enseigner et Apprendre En Contexte de Pandémie. Formation et Profession: Revue Scientifique International En Éducation; Bibliothèque nationale du Québec: Montréal, QC, Canada, 2020.

14. Karsenti, T.; Poellhuber, B.; Roy, N.; Parent, S. Le numérique et l'enseignement au temps de la COVID-19 entre défis et perspectives-Partie 1. Rev. Int. Technol. Pédagogique Univ. 2020, 17, 1-4.

15. Brugeilles, C.; Cromer, S. Comment Promouvoir l'égalité Entre Les Sexes Par Les Manuels Scolaire?: Guide Méthodologique à l'attention Des Acteurs et Actrices de La Chaîne Du Manuel Scolaire; UNESCO: Paris, France, 2008.

16. Memaï, A.; Rouag, A. Le manuel scolaire: Au-delà de l'outil pédagogique, l'objet Politico-Social. Éduc. Soc. 2017. [CrossRef]

17. Bruillard, É. Les Groupes Thématiques Numériques_Groupe Thématique Numérique 6: Mode d'appropriation Des Ressources; Ministère l'Éducation nationale et de la Jeunesse: Luxembourg, 2019.

18. Cherif, S.; Gekiere, G. Enseigner Autrement Avec Le Numérique: La Boîte à Outils Du Professeur; Dunod: Malakoff, France, 2017.

19. Dennis, A. E-Textbooks at Indiana University: A Summary of Two Years of Research; Indiana University Kelly School of Busness Research Report; Indiana University: Bloomington, IN, USA, 2011.

20. Weisberg, M. Student attitudes and behaviors towards digital textbooks. Publ. Res. Q. 2011, 27, 188-196. [CrossRef]

21. Pascarella, E.T.; Terenzini, P.T. How College Affects Students: A Third Decade of Research; Jossey-Bass: San Francisco, CA, USA, 2005.

22. Chickering, A.W.; Gamson, Z.F. Seven principles for good practice in undergraduate education. Biochem. Educ. 1989, 17, 140-141. [CrossRef]

23. Daniel, D.B.; Woody, W.D. E-textbooks at what cost? Performance and use of electronic v. print texts. Comput. Educ. 2013, 62, 18-23. [CrossRef]

24. Landrum, R.E.; Gurung, R.A.R.; Spann, N. Assesments of textbook usage and the relarionship to student course performance. Coll. Teach. 2012, 60, 17-24. [CrossRef]

25. Pittet, A.; Eberhard, C. «Filles Littéraires»: Stéréotype Ou Réalité? Une Étude de Cas Dans l'enseignement Des Langues Étrangères Au Secondaire II; Haute Ecole Pédagogique: Lausanne, France, 2017.

26. HCP. Enquête Sur l'impact Du Coronavirus Sur La Situation Économique, Sociale et Psychologique Des Ménages; Haut Commissariat au Plan du Maroc: Casablanca, Morocco, 2020.

27. Lynch, R.; Dembo, M. The relationship between self-regulation and online learning in a blended learning context. Int. Rev. Res. Open Distrib. Learn. 2004, 5. [CrossRef]

28. Davies, B.S.; Rafique, J.; Vincent, T.R.; Fairclough, J.; Packer, M.H.; Vincent, R.; Haq, I. Mobile medical education (MoMEd)—How mobile information resources contribute to learning for undergraduate clinical students-A mixed methods study. BMC Med. Educ. 2012, 12, 1. [CrossRef] 